\title{
Defluoridation by coagulation in drinkable water from the south east of Algeria
}

\author{
Djamel Atia, Abdelghani Hoggui \\ Laboratoire de Valorisation et Technologie des Ressources Sahariennes, \\ Département Sciences de la Matière, Institut des Sciences et Technologie Centre, \\ Université de Ouargla, Ouargla, Algérie \\ E-mail address: atia.sahan1@gmail.com
}

\begin{abstract}
The drinkable water in the south east of Algeria contains high quantity of fluoride which causes dental fluorosis. To decrease fluoride, we have chosen a sample with the biggest content of fluoride among many sources in order to coagulate it with $\mathrm{Al}_{2}\left(\mathrm{SO}_{4}\right)_{3} \cdot 18 \mathrm{H}_{2} \mathrm{O}$. After that the parameters influencing (concentration, $\mathrm{pH}$, temperature) are studied to choose the best conditions for better reduction yield.
\end{abstract}

Keywords: Coagulation; Defluoidation; Fluorosis; Oasis water

\section{INTRODUCTION}

The water of the south east of Algeria is characterized by high concentrations of fluoride, associated with severely high and excessive total mineralization. This water is the only source of drinking. The hot and dry climate has forced people to consume a lot of water which leads to raise the daily consumption rate of fluoride. In addition the eating a lot of dates and tea leads to the spread of fluorisis disease [1] which is characterized by the yellowish of tooth enamel according to the classification of the national program of school health $[2,3]$. To prevent these diseases from happening or reduce them, many techniques of defluoridation are used such as: membrane technologies, precipitation and adsorption. Our study is focused on adsorption with sulfate aluminium salt and determination of optimal conditions affecting the reduction of fluoride in drinking water.

\section{EXPERIMENTAL SECTION}

\section{1. Preparation of fluoride curve witness}

To determine the concentration of fluoride inVarious samples, a potentiometer method was used (Rodier 2005) [4]. Different standard concentration solutions were prepared from $\mathrm{NaF}$ salt in cups of plastic. Then their potential is measured by using specific fluoride pole (ISE15381/1) and a pH-meter model (pH211), using a solution of TISAB ${ }^{(6)}$. The graph $\mathrm{E}=$ $\mathrm{f}\left(\log \mathrm{C}_{\mathrm{F}}\right)$ is presented in Figure 1. 


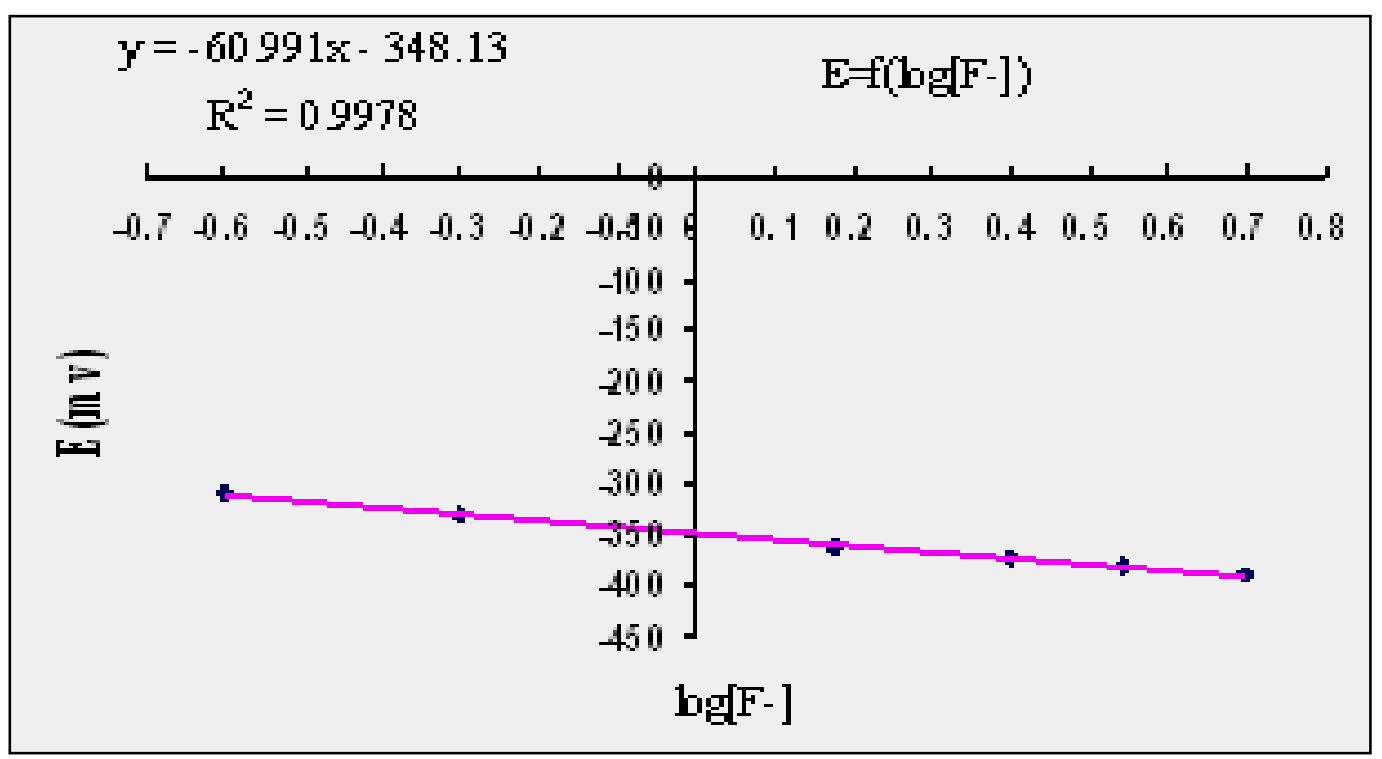

Figure 1. The witdess graph for fluoride

\section{2. Determination of fluoride concentration in some samples of the study area}

The concentration of fluoride has been determined in some water sources of the study area in order to determine and treat the largest content of fluoride. The results are presented in Table 1. The selected sample (cold water of Shuhada) has a concentration of fluoride 2.61 (mg/1).

Table 1. Fluoride concentration for some water in the studied area at $\mathrm{T}=19.3{ }^{\circ} \mathrm{C}$

\begin{tabular}{|c|c|c|c|c|c|c|c|}
\hline $\begin{array}{c}\text { Sources } \\
\text { of water }\end{array}$ & $\begin{array}{c}\text { mars } \\
\text { city }\end{array}$ & $\begin{array}{c}\text { mastur } \\
\text { city }\end{array}$ & $\begin{array}{c}\mathbf{4 0 0} \\
\text { city }\end{array}$ & $\begin{array}{c}\mathbf{8 m a y} \\
\text { city }\end{array}$ & $\begin{array}{c}\text { 1Nov } \\
\text { City }\end{array}$ & $\begin{array}{c}\text { Nezla } \\
\text { city }\end{array}$ & Shuhada \\
\hline $\begin{array}{c}{\left[\mathrm{F}^{-}\right]} \\
(\mathrm{mg} / \mathrm{l})\end{array}$ & 1.87 & 1.90 & 1.92 & 1.84 & 1.94 & 0.46 & 2.61 \\
\hline
\end{tabular}

\section{3. Determination of the predominant concentration of ions in the studied water} follows:

The study was done according to (Rodier 2005) [4] on cold water of Shuhada as

\section{3. 1. Nitrates and sulfates}

Spectroscopy method (UV) ray using ( spectrophotometer DR 2400). 


\section{3. 2. Total hardness}

By complexity with EDTA ${ }^{(1)}$ in the presence of Eriochrome Black T at buffer solution of $\mathrm{pH}=10$.

\section{3. 3. Sodium and potassium} Table 2.

Using flame atomic absorption analysis. Results of Predominant ions are presented in

Table 2. Physico-chemistry properties of Shuhada water.

\begin{tabular}{|c|c|c|c|c|c|c|c|c|c|}
\hline Property & $\mathbf{S O}_{4}{ }^{2-}$ & $\mathbf{C a}^{2+}$ & $\mathbf{M g}^{2+}$ & $\mathbf{N a}^{+}$ & $\mathbf{K}^{+}$ & $\mathbf{N O}_{3}^{-}$ & $\mathbf{T A}$ & $\mathbf{T A C}$ & $\mathbf{C l}^{-}$ \\
\hline $\begin{array}{c}\mathbf{C} \\
\mathbf{m g} / \mathbf{l})\end{array}$ & 544 & 492 & 140 & 55 & 2.4 & 5.9 & 0 & 105 & 402 \\
\hline
\end{tabular}

\section{3. 4. Alkalinity}

Determining $\mathrm{TA}^{(4)}$ and $\mathrm{TAC}^{(\mathbf{5})}$ using $\mathrm{PhPh}^{(3)}$ and $\mathrm{MO}^{(2)}$ indicators respectively.

\section{3. 5. Chlorides}

Volumetric method for Mohr.

\section{3. 6. Calcium concentration}

By complexity with EDTA $^{(\mathbf{1})}$ in the presence of Murexide at a solution of $\mathrm{pH}=12$.

\section{3. 7. Magnesium concentration}

Calculated from the difference Total hardness and Calcium concentration. The results are presented in Table 2 .

\section{4. Treatment}

The factors affecting (mass, $\mathrm{pH}$, and temperature $\mathrm{T}$ ) were studied by the Coagulation method using $\mathrm{Al}_{2}\left(\mathrm{SO}_{4}\right)_{3} \cdot 18 \mathrm{H}_{2} \mathrm{O}$ with a purity of $(98-100) \%$.

\section{4. 1. Effect of aluminium concentration}

Based on the coagulation of fluoride on $\mathrm{Al}(\mathrm{OH})_{3}$ according to equilibrium (1). $100 \mathrm{ml}$ of Shuhada water was put in each cup of plastic then the $\mathrm{pH}$ and temperature $\mathrm{T}$ were measured, after that different amount of the same salt was added to each cup. After stirring for 3 minutes, they are left for a while then filtered, finally the amount of fluoride in the filtrate was measured. The results were presented in Table 3 and Figure 2. 
Table 3. Relation between the added aluminium and the residual fluoride $\left(\mathrm{pH}=7.30\right.$ and $\left.\mathrm{T}=21.2^{\circ} \mathrm{C}\right)$.

\begin{tabular}{|c|c|c|c|c|c|c|}
\hline$\left[\mathbf{A l}^{\mathbf{3}}\right] \mathbf{( m g / l )}$ & 2.0 & 2.4 & 2.8 & 3.2 & 4.0 & 4.8 \\
\hline$\left[\mathbf{F}^{-}\right] \mathbf{( m g / l )}$ & 1.79 & 1.57 & 1.41 & 1.28 & 1.09 & 0.96 \\
\hline
\end{tabular}

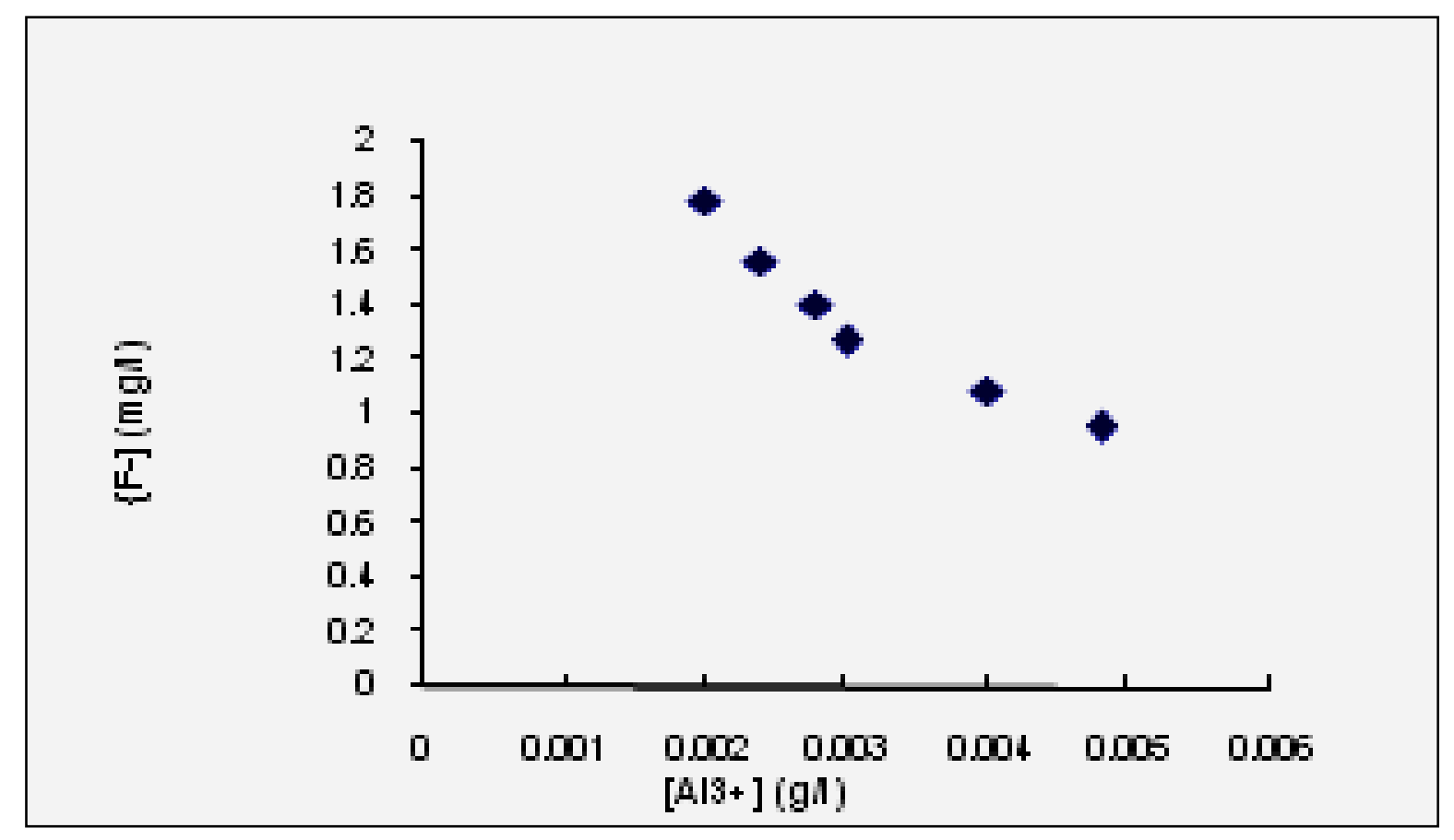

Figure 2. Variation of residual fluoride against added aluminium concentration.

\section{4. 2. Effect of $\mathrm{pH}$}

Based on adsorption of fluoride ion on $\mathrm{Al}(\mathrm{OH})_{3}$ which is related to the $\mathrm{pH}$ of the studied water according to the equilibrium (1).

We repeat the same steps of the previous experiment as mentioned in (2.4.1) by fixing the temperature and the added optimal concentration of aluminium sulfate but changing the $\mathrm{pH}$ by buffer solutions. The results are presented in Table 4 and Figure 3.

Table 4. Relation between the $\mathrm{pH}$ and the residual fluoride $\left[\mathrm{Al}^{3+}\right]=0.0024 \mathrm{~g} / 1, \mathrm{~T}=27.6{ }^{\circ} \mathrm{C}$.

\begin{tabular}{|c|c|c|c|c|c|}
\hline $\mathbf{p H}$ & $\mathbf{4 . 0 2}$ & $\mathbf{5 . 0 7}$ & $\mathbf{6 . 0 0}$ & $\mathbf{7 . 0 2}$ & $\mathbf{8 . 0 0}$ \\
\hline$\left[\mathbf{F}^{-}\right](\mathbf{m g} / \mathbf{l})$ & 1.80 & 1.46 & 1.23 & 1.27 & 1.50 \\
\hline
\end{tabular}




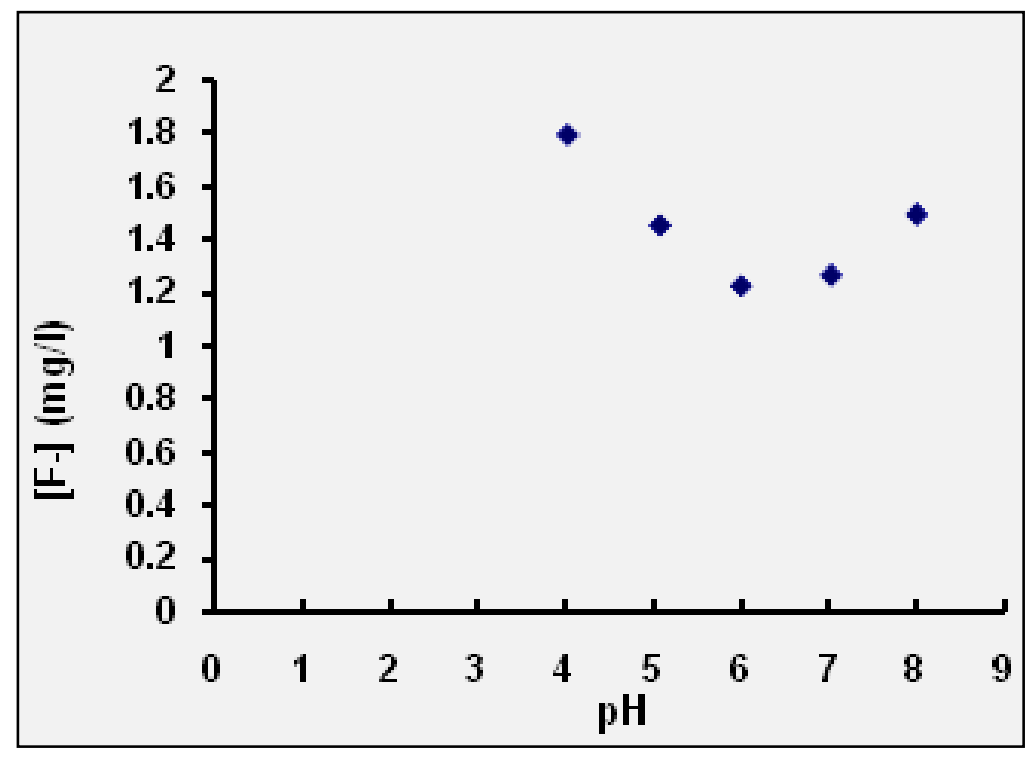

Figure 3. Variation of residual fluoride against $\mathrm{pH}$.

\section{4. 3. Effect of temperature $T$}

The same steps of the experiment are repeated as mentioned in (2.4.1) by fixing the added optimal concentration of $\mathrm{Al}_{2}\left(\mathrm{SO}_{4}\right)_{3}$ and the optimal $\mathrm{pH}$, but changing the temperature.

The results were presented in Table 5 and Figure 4 [5].

Table 5. Relation between the temperature and the residual fluoride $\left[\mathrm{Al}^{3+}\right]=0.0024 \mathrm{~g} / 1, \mathrm{pH}=8$.

\begin{tabular}{|c|c|c|c|c|c|}
\hline $\mathbf{T}\left({ }^{\circ} \mathbf{C}\right)$ & 20.0 & 26.5 & 30.0 & 40.0 & 45.0 \\
\hline$\left[\mathbf{F}^{-}\right](\mathbf{m g} / \mathbf{l})$ & 1.67 & 1.50 & 1.41 & 1.21 & 1.10 \\
\hline
\end{tabular}

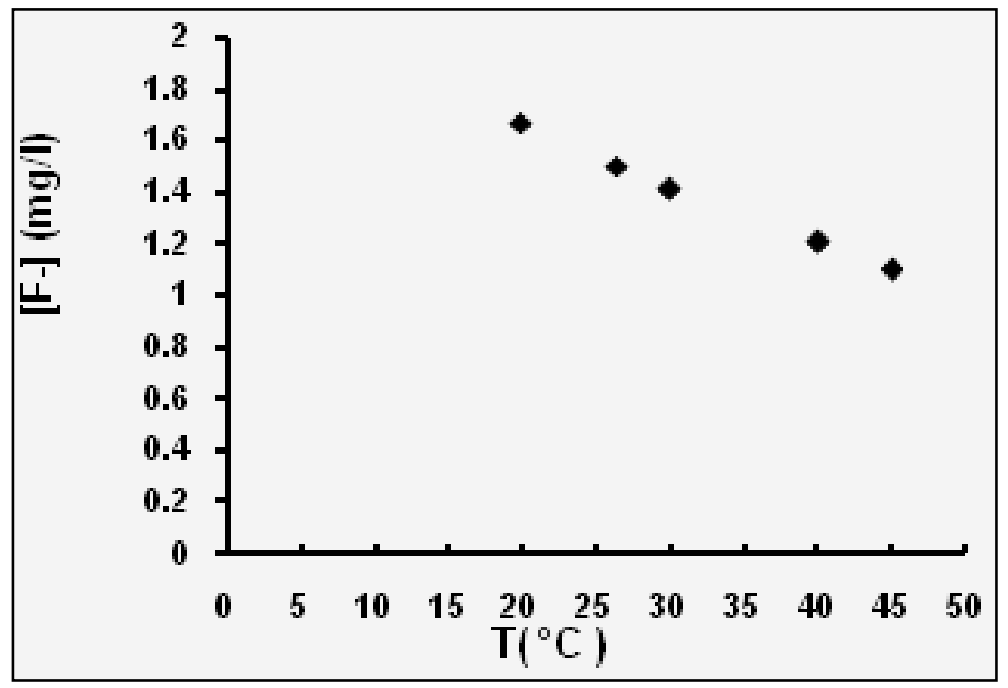

Figure 4. Variation of residual fluoride against temperature. 


\section{EQUATUON AND EQUILIBRIUM}

$$
\begin{aligned}
& 3 \mathrm{Ca}\left(\mathrm{HCO}_{3}\right)_{2}+\mathrm{Al}_{2}\left(\mathrm{SO}_{4}\right)_{3} \rightleftharpoons 3 \mathrm{CaSO}_{4}+2 \mathrm{Al}(\mathrm{OH})_{3(\mathrm{~S})}+6 \mathrm{CO}_{2} \ldots \text { (1) } \\
& \mathrm{Al}(\mathrm{OH})_{3(\mathrm{~S})}+3 \mathrm{H}_{3} \mathrm{O}^{+} \rightleftharpoons \mathrm{Al}^{3+}+6 \mathrm{H}_{2} \mathrm{O} \ldots \ldots \text { (2) } \\
& \mathrm{Al}(\mathrm{OH})_{3(\mathrm{~S})}+\mathrm{OH}^{-} \rightleftharpoons \mathrm{Al}(\mathrm{OH})_{4}{ }^{-} \ldots \ldots .(3) \\
& \eta=A e^{B / T} \\
& \mathrm{~V}=\frac{\mathrm{Z} \cdot \mathrm{D} \cdot \mathrm{E}}{4 \pi \eta} \ldots \ldots \ldots \\
& \mathrm{V}=\frac{\text { Z.D. E }}{4 \pi \eta}
\end{aligned}
$$

Where: $\eta=$ viscosity coefficient ;

$(\mathrm{A}, \mathrm{B})=$ constants related to the quality of the liquid;

$\mathrm{T}=$ temperature of solution;

$\mathrm{D}=$ dielectric constant of water;

$\mathrm{Z}=$ Zeta potential.

$\mathrm{E}=$ electric field intensity;

$\mathrm{V}_{\text {mob }}=$ speed of observed Particles:

$\mathrm{V}=$ speed of Particles in an electric field .

\section{RESULTS AND DISCUSSION}

According to the results of Table 2 we observe that the high concentrations of $\left(\mathrm{Ca}^{2+}, \mathrm{Mg}^{2+}, \mathrm{SO}_{4}{ }^{2-}, \mathrm{Cl}^{-}\right)$exceed the WHO standards of water. This related to the geological characteristics and the structure of rocks.

$\checkmark$ The results of Table 3 indicate that the concentrations of residual fluoride are decreased when the values of added aluminium concentration are increased. This can be explained by the formation of gelatinous aluminum hydroxide (equilibrum1) which adsorbs $\mathrm{F}^{-}[5]$. The optimal concentration of aluminium is $0.0024 \mathrm{~g} / 1$.

$\checkmark$ The results of table (4) show that:

- In acidic medium: The residual $\mathrm{F}^{-}$is decreased when the $\mathrm{pH}$ is increased which is proved by equilibrium (2).

- In basic medium: The residual $\mathrm{F}^{-}$is increased when the $\mathrm{pH}$ is increased which is proved by equilibrium (3).

The optimal chosen $\mathrm{pH}=7.6$ leads to a residual fluoride concentration equals $1.5 \mathrm{mg} / \mathrm{l}$ which fits the OMS standard.

$\checkmark$ According to the results of Table 5 we observe that residual $\left[\mathrm{F}^{-}\right]$is decreased when $\mathrm{T}$ is increased, this can be proved by the following: Increasing $\mathrm{T}$ leads to the decrease of [equation of Guzman-andrad] (1), so V is increased [equation (2)]. As a result $\mathrm{V}_{\text {mob }}$ is increased [equation (3)]. 
$\mathrm{V}_{\text {mob }}$ increases the probability of convergence $\mathrm{F}^{-}$from $\mathrm{Al}(\mathrm{OH})_{3}$ particles which augment the adsorption of $\mathrm{F}^{-}$on the surface of the particles $[6,7]$. The optimal chosen $\mathrm{T}=26.5^{\circ} \mathrm{C}$ leads to a residual fluoride concentration equals $1.5 \mathrm{mg} / \mathrm{l}$ which fits the OMS standard.

\section{CONCLUSION}

- According to the quantity of fluoride in the water of Oasis region of Algeria ,it appear that most of them Contain surplus exceeds the standard value of (WHO) ${ }^{(9)}$ with a total high hardness.

- The present investigation indicates that reducing fluoride from water is economic method because using a small amount of $\mathrm{Al}_{2}\left(\mathrm{SO}_{4}\right)_{3}$ is needed for this purpose.

- Through the study of factors affecting (concentration, $\mathrm{pH}$, temperature) it is possible to choose the best conditions for a reduction process with $\mathrm{Al}_{2}\left(\mathrm{SO}_{4}\right)_{3} \cdot 18 \mathrm{H}_{2} \mathrm{O}$ by adding an amount at a concentration of $0.030 \mathrm{~g} / 1, \mathrm{pH}=7.6$ and a temperature of $26.5^{\circ} \mathrm{C}$.

\section{ABRIVIATIONS}

EDTA $^{(1)}$ : ComplexonIII (Ethylene diamine tetra acetic acid disodium salt).

$\mathrm{MO}^{(2)}$ : methyl orange

$\mathrm{Ph}_{\mathrm{Ph}}{ }^{(3)}$ : phenolphthalein

$\mathrm{TA}^{(4)}$ : alkalimetric title.

$\mathrm{TAC}^{(5)}$ : The complete alkalimetric title.

TISAB $^{(6)}$ : total ionic strength adjustment buffer

$\mathrm{WHO}^{(7)}$ : World Health Organization.

\section{Acknowledgment}

Authors are thankful to Dr. Bebba Ahmed Abdelhafid who helped as to do this research also we thank the head of Department of Analytic chemistry, Institute of Technology, Ouargla University, for providing laboratory facilities.

\section{References}

[1] WHO, Fluoride in drinking water, IWA Publishing, London, 2006.

[2] Programme National de Santé Bucco-Dentaire en Milieu Scolaire, Ministčre de la Santé et de la Population, Algérie, Mai 2001.

[3] Circulaire interministérielle du 07 Mai 2001 relative au Programme National de Santé Bucco-Dentaire en Milieu Scolaire, Ministčre de la Santé et de la Population, Ministčre de l'Education Nationale, Algérie.

[4] Jean Rodier et coll., L'analyse de l'eau:eaux naturelles, eaux résiduaires, eau de mer, 8 édition; Paris 2005, pp. 219-221 and 299-310. 
[5] Achour, Youcef, Leïla Samia, Defluoruration des eaux souterraines du sud algerienne par la chaux et le sulfate d'aluminium, Université Mohamed KhiderBiskra, Algérie, 2001.

[6] Yaping Zhao, Xiuyan Li, Lu Liu, Fuhua Chen, Carbohydrate Polymers 72(1) (2008) 144-150.

[7] M. G. Sujana, G. Soma, N. Vasumathi, S. Anand, Journal of Fluorine Chemistry 130(8) (2009) 749-754. 